\title{
Effect of LH on circulating oestradiol and follicular fluid factor concentrations during follicle deviation in cattle
}

\author{
O. J. Ginther, D. R. Bergfelt, M. A. Beg and K. Kot \\ Department of Animal Health and Biomedical Sciences, University of Wisconsin, \\ Madison, WI 53706, USA
}

Progesterone was used to reduce $\mathrm{LH}$ concentrations starting at the time when the largest follicle was $\geqslant 5.7 \mathrm{~mm}$ in diameter or well before the expected start of follicle deviation (largest follicle $\geqslant 8.5 \mathrm{~mm}$ in diameter). Plasma concentrations of $\mathrm{LH}, \mathrm{FSH}$ and oestradiol were determined at $\mathbf{4} \mathrm{h}$ intervals in control and progesterone-treated heifers ( $n=8$ per group). Concentrations of LH were lower $(P<0.05)$ in the progesterone-treated group, reflecting an absence of the transient increase in LH concentrations that encompasses follicle deviation. An increase in oestradiol and a continued decrease in FSH occurred at the start of follicle deviation in the control cows but not in the treated heifers. In a second experiment, follicular fluid of the two largest follicles of control and progesterone-treated heifers was sampled at the expected start of deviation $(n=8-10$ per group). The concentrations of oestradiol, but not androstenedione and free insulin-like growth factor I (IGFI), in follicular fluid were higher $(P<\mathbf{0 . 0 0 1})$ in the largest follicle than in the second largest follicle. Progesterone treatment reduced $(P \leqslant 0.02)$ the concentrations of all three factors in follicular fluid and increased $(P<0.05)$ the concentrations of insulin-like growth factor binding protein 2 (IGFBP-2). These results confirm that oestradiol contributes to the continued decrease in FSH concentrations after the start of follicle deviation. Prevention of the transient LH increase, the oestradiol increase and the continued FSH decrease did not significantly alter the mean time or follicle diameters characteristic of expected follicle deviation. However, in some treated individuals (three of eight), the observed follicle deviation was delayed. In addition, these results indicate that the secretion of oestradiol into the circulation and the increase in oestradiol and IGF-I and decrease in IGFBP-2 concentrations in the follicular fluid at the start of deviation are functions of the transient increase in LH concentrations that encompasses follicle deviation.

\section{Introduction}

Deviation in follicle diameter occurs during follicular wave development in cattle and is characterized by a continued growth rate of the largest follicle (developing dominant follicle) and a reduced growth rate of the remaining follicles (developing subordinate follicles; for a review see Ginther, 2000). The start of deviation is defined as occurring at the ultrasound examination preceding the examination in which the diameter difference between the two largest follicles has increased, and occurs on average when the largest follicle first reaches $\geqslant 8.5 \mathrm{~mm}$ in diameter. The decrease in $\mathrm{FSH}$ concentrations of the surge that stimulates the development of the wave is an integral part of deviation (Ginther, 2000). The FSH concentrations continue to decrease for 10-20 $\mathrm{h}$ after the start of deviation, which is due, at least in part, to secretion of oestradiol by the largest follicle (Ginther et al., 2000a). Regression of the lessdeveloped smaller follicles is attributable to the low FSH concentrations at the start of deviation, but it is not known whether the subsequent continued decrease in $\mathrm{FSH}$ concentrations is required for continued suppression of

Email: ojg@ahabs.wisc.edu subordinate follicles. The more developed larger follicle continues to use the self-imposed basal FSH concentrations (Ginther et al., 2000b). Substances found in the follicular fluid, such as oestradiol, insulin-like growth factor I (IGF-I) and insulin-like growth factor binding proteins (IGFBPs) may play a role in follicle deviation by enhancing the ability of the largest follicle to use the low FSH concentrations or by facilitating conversion of the largest follicle to increased LH dependency (Ginther, 2000). Ginther et al. (2001) demonstrated that concentrations of free IGF-I were greater in the largest follicle than in the second largest follicle, but only once follicle deviation had started.

A transient increase in circulating $\mathrm{LH}$ concentrations encompasses the start of follicle deviation (Ginther, 2000). The effect of $\mathrm{LH}$ on follicle diameter has been studied in heifers (Ginther et al., 2001) and mares (Gastal et al., 1999) by reducing circulating $\mathrm{LH}$ concentrations experimentally using progesterone. In both species, the decrease in $\mathrm{LH}$ concentrations interfered with the growth of the dominant follicle starting on day 1 or 2 after the beginning of deviation, but did not alter the time of deviation or the growth and regression profile of the largest subordinate follicle. Experimental reduction of $\mathrm{LH}$ concentrations by progesterone resulted in a decrease in the concentrations of oestradiol and IGF-I in follicular fluid well after the 
expected time of deviation (mean diameter for largest follicle $10.8 \mathrm{~mm}$ ) but not near the start of deviation (largest follicle $8.7 \mathrm{~mm}$ in diameter) (Ginther et al., 2001). A role for the transient increase in $\mathrm{LH}$ concentrations in initiation of deviation was not found in these experiments.

In the present study the following hypotheses were tested: (i) that the transient increase in LH concentrations is used to increase plasma oestradiol concentrations at the start of deviation in follicle diameter; (ii) that the increase in oestradiol concentrations contributes to the continued decrease in FSH concentrations after deviation; and (iii) that follicular fluid concentrations of oestradiol and free IGF-I are stimulated by LH.

\section{Materials and Methods}

\section{Animals and ultrasonography}

Two experiments were conducted during the wave that emerges during the periovulatory period (wave 1). The animals were Holstein heifers aged between 24 and 36 months. The feeding programme, the $\mathrm{PGF}_{2 \alpha}$ protocol for inducing luteolysis to schedule ovulation and the equipment and techniques for transrectal ultrasonography of the ovaries and measurement of the follicles have been described previously (Ginther, 1998; Ginther et al., 2000b). Scanning was done at $24 \mathrm{~h}$ intervals starting on the day of induced luteolysis and continuing until the largest follicle of a new wave was $5.0 \mathrm{~mm}$ in diameter. Thereafter, scanning was done at $12 \mathrm{~h}$ intervals. The hour of expected, rather than observed, deviation was used in both experiments to provide a common reference point for comparisons between the two experiments; follicular fluid was aspirated in Expt 2 at this time, obscuring the hour of observed deviation. Expected hour of deviation in individual waves was taken as the examination when the largest follicle first reached $\geqslant 8.5 \mathrm{~mm}$ in diameter, based on previous studies (Ginther, 2000). Hour of observed deviation was also determined in Expt 2 based on the first apparent change in the differences in diameter between the two largest follicles.

Progesterone (75 mg; Diosynth, Chicago, IL) was used to reduce the circulating concentrations of $\mathrm{LH}$. The progesterone was injected at $12 \mathrm{~h}$ intervals using $1 \mathrm{ml}$ safflower oil as the vehicle. The dosage was based on previous studies in which $75 \mathrm{mg}$ (Adams et al., 1992a) or 50 mg (Ginther et al., 2001) was administered every $12 \mathrm{~h}$ or $8 \mathrm{~h}$, respectively. Heifers were randomized into two groups to receive either 0 or $75 \mathrm{mg}$ progesterone. Animals in the $0 \mathrm{mg}$ group (controls) were given vehicle only. Progesterone treatment was started when the largest follicle first exceeded $5.7 \mathrm{~mm}$ in diameter, based on a previous study (Ginther et al., 2001). It was estimated that initiation of treatment when the largest follicle was $>5.7 \mathrm{~mm}$ in diameter would precede and prevent the increase in $\mathrm{LH}$ concentration before deviation.

\section{Experiment 1}

The four largest follicles were tracked by ultrasonography from examination to examination as described by
Ginther (1998). On the basis of the maximum diameter attained, the largest and second largest follicles were defined retrospectively as follicle 1 and follicle 2, respectively, and were used to assess the follicular effects of progesterone treatment ( $n=8$ heifers per group). Collection of jugular samples was by venepuncture at $12 \mathrm{~h}$ intervals for $72 \mathrm{~h}$ and samples were assayed for $\mathrm{LH}$ and $\mathrm{FSH}$ concentrations. When the largest follicle first exceeded 6.4 $\mathrm{mm}$ in diameter, a catheter was placed into the caudal vena cava with the tip of the catheter cranial to the entry of the ovarian veins (Ginther et al., 2000a). A $20 \mathrm{ml}$ blood sample was collected from the vena cava at $4 \mathrm{~h}$ intervals from the time at which the largest follicle was $>6.7 \mathrm{~mm}$ in diameter until the largest follicle (not necessarily the same follicle) was $>9.4 \mathrm{~mm}$ in diameter. The 6.7 and $9.4 \mathrm{~mm}$ criteria were based on previous findings (Ginther et al., 2001) and were used to minimize the interval that the heifers were exposed to the catheters without compromising the inclusion of deviation time. The vena cava samples were assayed for $\mathrm{LH}, \mathrm{FSH}$, oestradiol and immunoreactive inhibin and were normalized to the expected beginning of deviation $(t=0)$.

\section{Experiment 2}

Progesterone treatment ( $n=10$ heifers per group) was the same as for Expt 1 and continued at $12 \mathrm{~h}$ intervals until the largest follicle first reached $\geqslant 8.5 \mathrm{~mm}$ in diameter. Progesterone treatment was stopped at this time and follicular fluid was aspirated from each of the two largest follicles. The fluid samples were collected by ultrasoundguided transvaginal aspiration with a 20 ga needle as described by Ginther (1998), placed on ice and taken to the laboratory within $1 \mathrm{~h}$. The follicular fluid was assayed for oestradiol, oestrone, androstenedione, progesterone, immunoreactive inhibin, free IGF-I and IGFBP-2 concentrations.

\section{Hormone assays}

Blood samples were collected into heparinized tubes and the plasma was separated by centrifugation at $1500 \mathrm{~g}$ for $30 \mathrm{~min}$, decanted into storage vials and frozen $\left(-20^{\circ} \mathrm{C}\right)$ until assay. Plasma concentrations of $\mathrm{FSH}$ and $\mathrm{LH}$ were determined using a validated radioimmunoassay for cattle (Adams et al., 1992b). Mean assay sensitivities were $0.02 \mathrm{ng}$ FSH ml-1 and $0.16 \mathrm{ng} \mathrm{LH} \mathrm{ml}^{-1}$. The intra- and interassay coefficients of variation were 5.9 and $5.5 \%$, respectively, for $\mathrm{FSH}$, and 5.1 and $15.0 \%$, respectively, for $\mathrm{LH}$.

Follicular fluid samples were centrifuged at $500 \mathrm{~g}$ for 10 min to remove cells and stored at $-20^{\circ} \mathrm{C}$ until assay. Follicular fluid and plasma concentrations of oestradiol were determined using modifications of a radioimmunoassay kit (Second Antibody Oestradiol; Diagnostic Products Corporation, Los Angeles, CA; Turzillo and Fortune, 1990). The assay details for this laboratory have been reported for follicular fluid (Bergfelt et al., 2000) and for jugular (Ginther et al., 2000b) and caudal vena cava (Ginther et al., 2000a) plasma samples in cattle. For the assay of plasma, a 
modification was made for the extraction of $500 \mu$ l of each sample and $500 \mu$ l steroid-free (> 99\% reduction in steroids) bovine plasma. The modifications produced oestradiol concentrations that were about 50\% lower than for previous vena cava studies (Evans et al., 1997; Ginther et al., 2000a); however, the relative changes were similar to those reported previously for data normalized to the start of deviation (Ginther et al., 2000a). Follicular fluid samples were diluted 1:1000 in assay buffer for determining oestradiol concentrations. Mean assay sensitivity was $0.38 \mathrm{pg}$ oestradiol $\mathrm{ml}^{-1}$ for assays involving plasma and $3.1 \mathrm{pg}$ oestradiol $\mathrm{ml}^{-1}$ for assays involving follicular fluid. The intra- and interassay coefficients of variation were 3.3 and $11.4 \%$, respectively, for follicular fluid, and $8.3 \%$ and $2.5 \%$, respectively, for plasma.

Concentrations of oestrone (DSL-8700) and androstenedione (DSL-4200) in follicular fluid were determined using double antibody radioimmunoassay kits (Diagnostic Systems Laboratories Inc., Webster, TX). The kits were modified to use assay buffer (PBS with $0.1 \%(\mathrm{w} / \mathrm{v})$ gelatin) containing $2 \%(\mathrm{v} / \mathrm{v})$ steroid-free bovine follicular fluid to prepare oestrone (10-2000 $\mathrm{pg} \mathrm{m}^{-1}$ ) and androstenedione (0.078-20 ng ml-1) standards. A series of seven dilutions of a pool of follicular fluid ranging from 1:10 to 1:1000 in a total volume of $50 \mu \mathrm{l}$ with assay buffer resulted in displacement curves that were similar to the standard curves for oestrone and androstenedione. For follicular fluid samples, a dilution of 1:50 was used for both hormones. According to the manufacturer, the crossreactivity of the oestrone and androstenedione antisera with other steroids is minimal $(0.00-2.02 \%$ and $0.00-0.33 \%$, respectively). The mean assay sensitivities were $0.02 \mathrm{ng} \mathrm{ml}^{-1}$ and $0.003 \mathrm{ng} \mathrm{ml}^{-1}$ for oestrone and androstenedione, respectively. The intraassay coefficients of variation were 15.3 and $5.6 \%$ for low and high concentrations of oestrone, respectively, and 1.9 and $10.4 \%$ for low and high concentrations of androstenedione, respectively.

Follicular fluid concentrations of progesterone were determined using a competitive ELISA for cattle, using a dilution of 1:100 (Beg et al., 2001). Mean assay sensitivity was $0.02 \mathrm{ng} \mathrm{ml}^{-1}$. The intra- and inter-assay coefficients of variation were 6.5 and $<1.0 \%$, respectively, for low concentrations, and 5.2 and $2.0 \%$, respectively, for high concentrations.

Concentrations of immunoreactive inhibin in plasma and follicular fluid samples were determined using a radioimmunoassay kit (Institute of Reproduction and Development, Monash Medical Center, Clayton; Beg et al., 2001). The assay crossreacts with the full-length forms of the $\alpha$ subunit as well as the various intact forms of inhibin (Roser et al., 1994). Assay sensitivity was 2.9 ng immunoreactive inhibin $\mathrm{ml}^{-1}$. The intra-assay coefficients of variation for quality control samples were 7.6 and $11.0 \%$ for low and high concentrations, respectively.

Follicular fluid concentrations of free IGF-I were determined using a sandwich-type ELISA kit (DSL 10-9400; Diagnostic Systems Laboratories; Beg et al., 2001). Mean assay sensitivity was $0.01 \mathrm{ng}$ IGF-I $\mathrm{ml}^{-1}$. The intra- and interassay coefficients of variation were 2.3 and $1.1 \%$ for low concentrations and 6.4 and $3.5 \%$ for high concentrations, respectively.

Follicular fluid concentrations of IGFBP-2 were determined using a double antibody radioimmunoassay kit (DSL7100; Diagnostic Systems Laboratories Inc.; Beg et al., 2001). Mean assay sensitivity was $0.36 \mathrm{ng}$ IGFBP-2 $\mathrm{ml}^{-1}$. The intra- and inter-assay coefficients of variation were 10.8 and $10.4 \%$ for low concentrations and 12.8 and $6.1 \%$ for high concentrations, respectively.

\section{Statistical analyses}

For sequential gonadotrophin data (Expt 1), split-plot ANOVA was used for determining the main effects of group and hour and the interaction. Variation due to sequential data was accounted for by using heifer within group as the error term to test the effect of group. If a significant effect of hour or an interaction of group by hour was indicated, differences between groups within hours and among hours within a group were examined further by unpaired and paired Student's $t$ tests, respectively. The concentrations of $\mathrm{FSH}$ in the jugular samples of Expt 1 were converted to percentage change from the concentrations at the first progesterone treatment. Percentages were used because of a disparity between the $0 \mathrm{mg}$ and $75 \mathrm{mg}$ group means at the first sample. It was thought that the disparity, although not significant, could contribute to significant differences at other hours. In this regard, a significant correlation in FSH concentrations between days within heifers has been reported (Ginther et al., 2001). For percentage data, values for the first sample were not included in the statistical analyses because of the absence of variation. Percentage conversion was not used for other analyses because the means from the first sample were similar among groups. In Expt 2, the follicular fluid factors were analysed by a two $x$ two factorial ANOVA. The main effects were follicles (largest and second largest) and groups (control and treated). No significant interactions were found for any of the follicular fluid factors and the data were not analysed further. According to the Kolmogorov-Smirnov test, the observations for oestradiol, oestrone, progesterone, androstenedione and free IGF-I were not distributed normally. These end points were subjected to a logarithmic transformation before the ANOVA. Deviation end points (follicle diameters and hour of occurrence) were analysed by one-way ANOVA. Data are presented as the mean \pm SEM unless indicated otherwise. The level of significance $P<0.05$ was defined as significant. Probabilities between $P>0.06$ and $P<0.10$ were considered as approaching significance.

\section{Results}

\section{Experiment 1}

For the follicular data normalized to the beginning of treatment, the hour effect was significant for diameter of the largest (follicle 1) and second largest (follicle 2) follicles, 

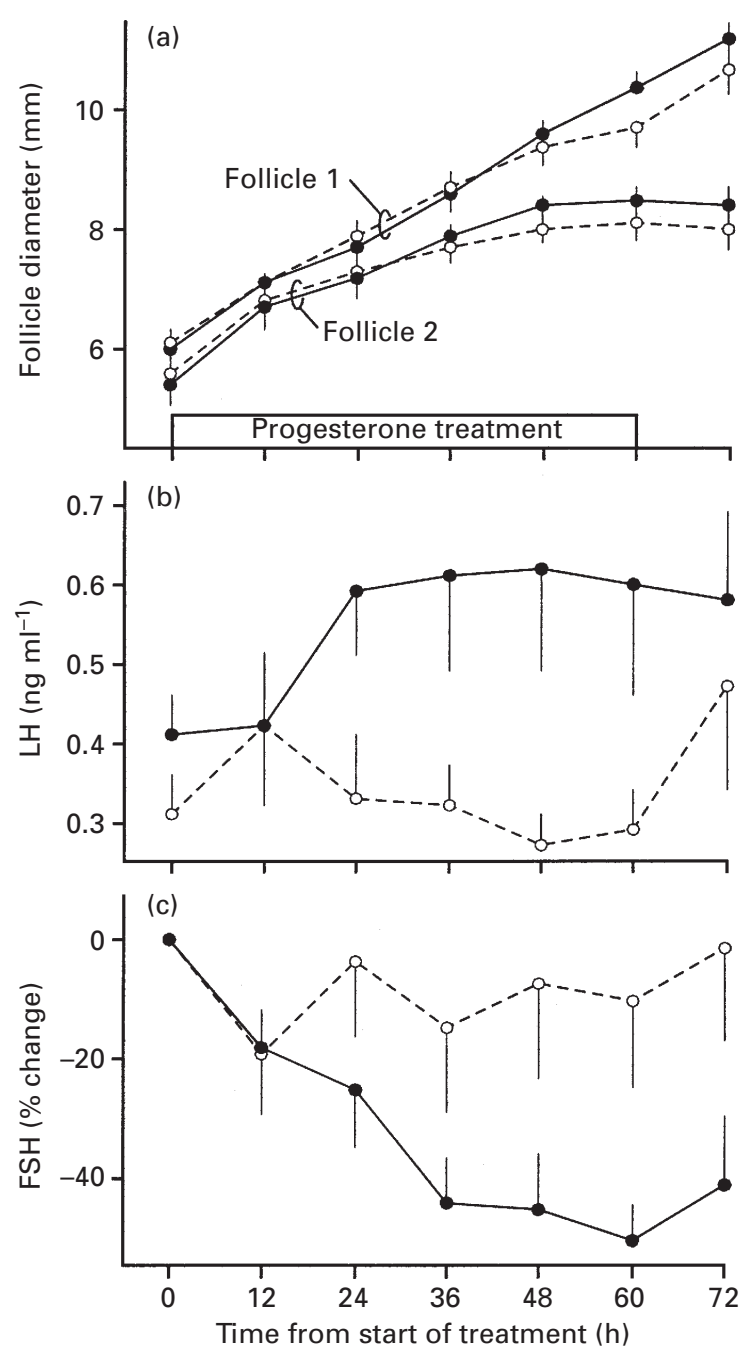

Fig. 1. (a) Diameters of the two largest follicles (follicle 1: largest follicle; follicle 2: second largest follicle), (b) LH concentrations and (c) percentage change in FSH concentration in jugular venous samples in heifers ( $n=8$ per group) treated with $0 \mathrm{mg}(\mathbf{0}$; control group) or $75 \mathrm{mg}(\bigcirc$; treated group) progesterone at $12 \mathrm{~h}$ intervals. Treatment was started when the largest follicle was $>5.7 \mathrm{~mm}$ in diameter. Values are mean \pm SEM. There was a significant effect of group for LH only $(P<0.05)$. There was a significant effect of hour for diameter of follicles 1 and 2 (both $P<0.0001$ ) and change in FSH concentration $(P<0.02)$. There was a significant group by hour interaction for diameter of follicle $1(P<0.05)$ and change in FSH concentration $(P<0.01)$.

reflecting the increasing diameters of both follicles. The group effect (controls versus treated) was not significant for either of the follicles and the group by hour interaction was significant for follicle 1 only (Fig. 1). The diameter of follicle 1 was smaller $(P<0.05) 60 \mathrm{~h}$ after the start of treatment in the treated group $(9.7 \pm 0.3 \mathrm{~mm})$ than in the control group $(10.4 \pm 0.3 \mathrm{~mm})$. The time from the start of treatment to the expected deviation in follicle diameters was not significantly different between the control $(37.5 \pm 2.7 \mathrm{~h})$ and treated $(39 \pm 4.4 \mathrm{~h})$ groups. The interval from the start of treatment to observed follicle deviation was shorter in the control group $(37.5 \pm 3.5 \mathrm{~h})$ than in the treated group $(45.0 \pm 5.4 \mathrm{~h})$, although this difference was not significant. The three longest intervals $(\geqslant 60 \mathrm{~h}$ ) all occurred in the treated group ( $3 / 8$ versus $0 / 8 ; P<0.05$ ).

Concentrations of $\mathrm{LH}$ in jugular samples were lower in the treated group than in the control group (Fig. 1). There was a significant difference $(P<0.02)$ between the two groups at $24,36,48$ and $60 \mathrm{~h}$ after the start of treatment. Within the controls, the LH concentrations increased $(P<0.05)$ between $0 \mathrm{~h}$ and $24 \mathrm{~h}$ after the start of treatment, but there were no significant changes in the treated group. The concentrations of FSH in the jugular samples showed a group by hour interaction, with higher $(P<0.05) \mathrm{FSH}$ concentrations in the treated group than in the control group at 36, 48, 60 and $72 \mathrm{~h}$ after the start of treatment (Fig. 1). FSH concentrations decreased progressively $(P<0.05)$ between $12 \mathrm{~h}$ and $60 \mathrm{~h}$ within the controls, but not within the treated group.

The vena cava samples were normalized to the expected time of deviation $(t=0)$, and data were truncated at $t=-8 \mathrm{~h}$ to $t=24 \mathrm{~h}$ because of missing values (Fig. 2). Concentrations of LH were lower (group effect) in the progesteronetreated group, with a difference $(P<0.05)$ between groups for $t=-4 \mathrm{~h}$ to $t=24 \mathrm{~h}$. Concentrations of FSH were higher in the treated group (group effect), although the difference was not significant. Within the control group, the FSH concentrations decreased $(P<0.02)$ between $t=-8 \mathrm{~h}$ and $t=8 \mathrm{~h}$ and the decline between $t=0 \mathrm{~h}$ and $t=8 \mathrm{~h}$ approached significance $(P<0.07)$. A significant decrease in $\mathrm{FSH}$ concentrations was not found within the treated group. For oestradiol concentrations, the two main effects and the interaction were significant. Concentrations were lower $(P<0.05)$ in the treated group between $t=8 \mathrm{~h}$ and $t=24 \mathrm{~h}$, except for $t=16 \mathrm{~h}$. Concentrations increased $(P<0.05)$ after $t=0 \mathrm{~h}$ within the controls, but there were no significant differences within the treated group. No significant differences were found for immunoreactive inhibin concentrations.

\section{Experiment 2}

Data for one of the second largest follicles were removed from the analyses for all end points because it appeared to be a co-dominant follicle (diameter of two largest follicles: 9.3 and $9.1 \mathrm{~mm}$; oestradiol concentrations in follicular fluid: 331 and $295 \mathrm{ng} \mathrm{ml}^{-1}$ ). One or two observations were unavailable from each of the follicular fluid end points of the second largest follicle because of an inadequate follicular fluid sample. Data and results of analyses for the two largest follicles in the control and treated groups are shown (Table 1). Averaged over both follicles, treatment at the expected start of deviation significantly decreased the concentrations of oestradiol, oestrone, androstenedione and free IGF-I in follicular fluid and increased the concentrations of IGFBP-2. Treatment did not affect follicle diameter or concentrations of progesterone or immunoreactive inhibin. Only follicle diameter and concentration 
of oestradiol were significantly different between the two largest follicles as indicated by a main effect of follicle. There were no significant follicle by treatment interactions.

\section{Discussion}

In the controls, $\mathrm{LH}$ concentrations increased between $0 \mathrm{~h}$ and $24 \mathrm{~h}$ after the start of treatment, representing the initial portion of the transient increase in $\mathrm{LH}$ concentrations that encompasses deviation during the first wave (Ginther, 2000; Ginther et al., 2001). This increase did not occur in the treated group; concentrations were lower in the treated group than in the controls from $24 \mathrm{~h}$ after the start of treatment. In the vena cava samples collected $4 \mathrm{~h}$ after the start of treatment, the transient increase in $\mathrm{LH}$ concentrations that encompasses deviation was present in the controls but not in the treated group. Thus, the treatment prevented the LH increase that usually occurs at follicle deviation, effectively testing the hypotheses. The reduced $\mathrm{LH}$ concentration was associated with reduced diameter of the dominant follicle $60 \mathrm{~h}$ after the start of treatment or about 1 day after the start of deviation. The time of expected deviation and the changing diameters of follicle 2 (second largest follicle) were not affected. These results indicated that $\mathrm{LH}$ was not used for initiating deviation when based on diameters alone, but was needed for continued growth of the dominant follicle after deviation. These results confirmed previous findings in cattle (Ginther et al., 2001) and horses (Gastal et al., 1999). Although the effects of progesterone are attributed to the reduced concentrations of $\mathrm{LH}$, a direct effect of progesterone on the follicles cannot be ruled out.

From the start of Expt 1, the concentrations of $\mathrm{FSH}$ obtained at $12 \mathrm{~h}$ intervals decreased in the control group, representing the well documented decrease in the wavestimulating FSH surge (Ginther, 2000). After the start of treatment, cessation of the $\mathrm{FSH}$ decrease in the treated group occurred at the time of prevention of the increase in LH concentration associated with deviation. The first significantly greater concentration of $\mathrm{FSH}$ in the treated group compared with the control group was $36 \mathrm{~h}$ after the start of progesterone treatment or within a mean of $3 \mathrm{~h}$ from the time of expected deviation. In the $4 \mathrm{~h}$ vena cava samples, the FSH decrease approached significance between $t=0 \mathrm{~h}$ and $t=12 \mathrm{~h}$ in the controls. A continued decrease in FSH concentrations for 10-20 h after the start of deviation has been demonstrated consistently (Ginther, 2000). A decrease in FSH concentrations did not occur in the treated group after deviation, and the FSH concentrations were higher in the treated group, averaged over all samples.

The increase in oestradiol concentration in the plasma samples of controls collected from the vena cava start at the expected hour of deviation (increase after $t=0 \mathrm{~h}$ ). This result agrees with the result of a previous study of circulating oestradiol (Ginther et al., 2000a). Oestradiol was the only follicular fluid factor that was present at higher
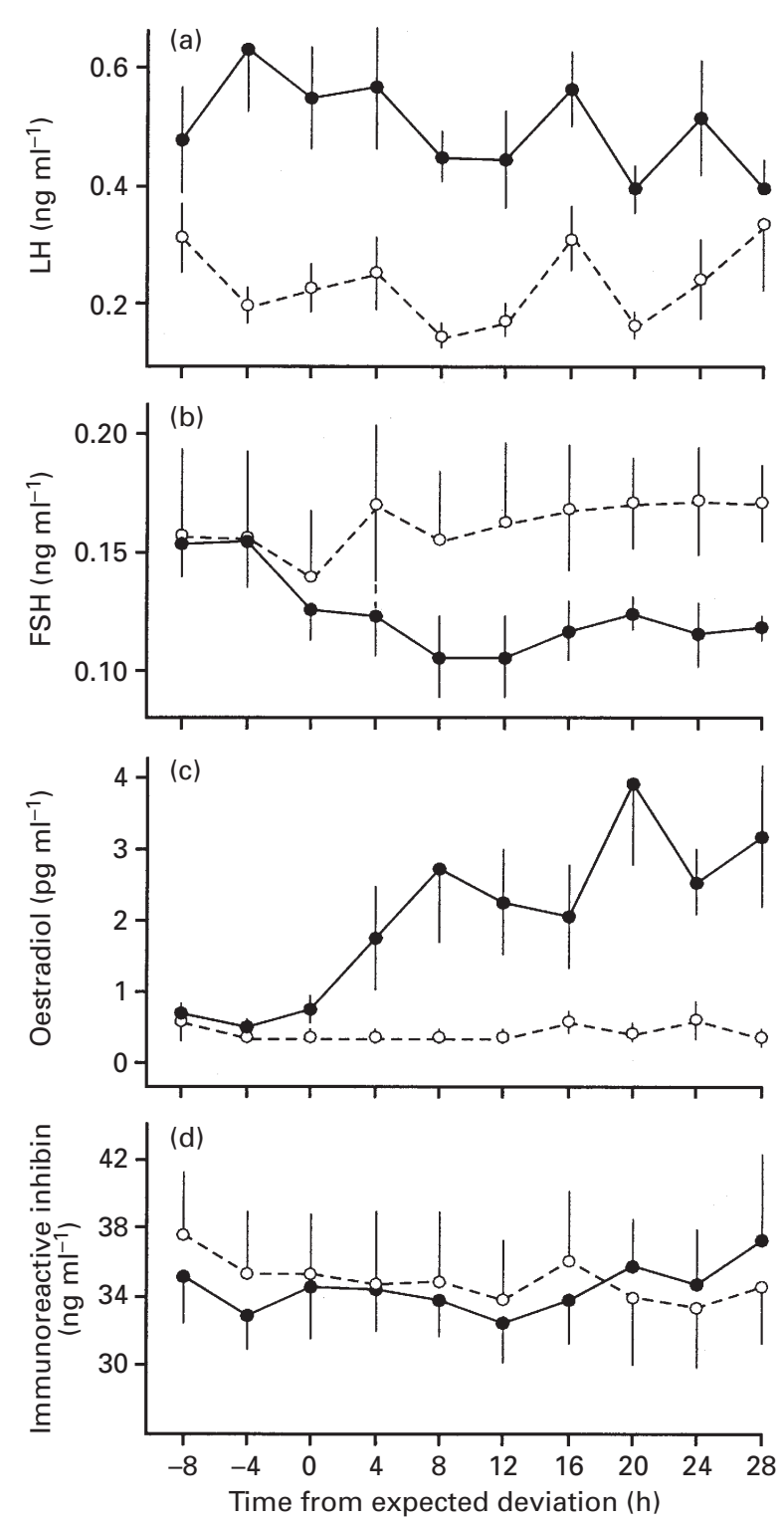

Fig. 2. Circulating concentrations of (a) LH, (b) FSH, (c) oestradiol and (d) immunoreactive inhibin in vena cava samples from heifers ( $n=8$ per group) treated with $0 \mathrm{mg}(\mathbf{0}$; control group) or $75 \mathrm{mg}(\bigcirc$; treated group) progesterone at $12 \mathrm{~h}$ intervals. Data are normalized to the expected start of deviation in follicle diameter (largest follicle, $\geqslant 8.5 \mathrm{~mm}$ in diameter). Values are mean \pm SEM. The group effect (control versus treated) was significant for $\mathrm{LH}(P<0.001)$, FSH $(P<0.005)$ and oestradiol $(P<0.0001)$. The group by hour interaction was significant for oestradiol only $(P<0.05)$.

concentrations in the largest follicle than in the second largest follicle at the expected start of deviation. The start of a difference in diameter between the two largest follicles occurred at the same time as the start of a difference in follicular fluid oestradiol concentration observed in previous studies (Ginther et al., 1997; Beg et al., 2001).

Plasma oestradiol concentrations did not increase in the progesterone-treated group and were lower than in the control group by $t=8 \mathrm{~h}$. Furthermore, in Expt 2, decreased 
Table 1. Diameter of follicles and concentrations of follicular fluid factors at the expected start of follicle deviation (largest follicle $\geqslant 8.5 \mathrm{~mm}$ in diameter) in response to progesterone treatment and the associated reduction in LH concentration in cattle (Expt 2)

\begin{tabular}{|c|c|c|c|c|c|}
\hline \multirow[b]{2}{*}{ End points } & \multicolumn{2}{|c|}{ Largest follicle } & \multicolumn{2}{|c|}{ Second largest follicle } & \multirow[b]{2}{*}{ Main effects ${ }^{\mathrm{a}}$} \\
\hline & Control & Treated & Control & Treated & \\
\hline Diameter (mm) & $9.0 \pm 0.1$ & $8.7 \pm 0.1$ & $7.5 \pm 0.2$ & $7.5 \pm 0.2$ & Follicle: $P<0.0001$; Treatment: $\mathrm{ns}$ \\
\hline Oestradiol $\left(\mathrm{ng} \mathrm{ml}^{-1}\right)$ & $440.0 \pm 104.8$ & $156.3 \pm 53.2$ & $215.8 \pm 74.2$ & $29.0 \pm 12.5$ & Follicle: $P \leqslant 0.001$; Treatment: $P \leqslant 0.002$ \\
\hline Oestrone $\left(\mathrm{ng} \mathrm{ml}^{-1}\right)$ & $53.0 \pm 17.4$ & $12.9 \pm 3.4$ & $31.9 \pm 8.3$ & $8.9 \pm 3.3$ & Follicle: ns; Treatment: $P<0.001$ \\
\hline Androstenedione $\left(\mathrm{ng} \mathrm{ml}^{-1}\right)$ & $56.9 \pm 30.5$ & $17.5 \pm 9.1$ & $33.3 \pm 8.7$ & $15.9 \pm 8.9$ & Follicle: ns; Treatment: $P \leqslant 0.002$ \\
\hline Progesterone $\left(\mathrm{ng} \mathrm{ml}^{-1}\right)$ & $189.6 \pm 129.4$ & $53.5 \pm 16.4$ & $67.8 \pm 24.2$ & $93.2 \pm 51.5$ & Follicle: ns; Treatment: ns \\
\hline $\begin{array}{l}\text { Immunoreactive inhibin } \\
\left(\mu \mathrm{gl}^{-1}\right)\end{array}$ & $476.7 \pm 84.4$ & $478.8 \pm 41.9$ & $443.8 \pm 51.2$ & $453.6 \pm 71.9$ & Follicle: ns; Treatment: ns \\
\hline Free IGF-I (ng ml-1) & $9.8 \pm 2.4$ & $6.5 \pm 1.7$ & $8.3 \pm 1.3$ & $5.8 \pm 2.5$ & Follicle: ns; Treatment: $P \leqslant 0.02$ \\
\hline IGFBP-2 (ng ml-1) & $576.3 \pm 48.5$ & $696.5 \pm 47.7$ & $528.6 \pm 48.9$ & $685.4 \pm 93.5$ & Follicle: ns; Treatment: $P<0.03$ \\
\hline
\end{tabular}

Values are mean \pm SEM ( $n=8-10$ observations).

Progesterone treatment was given at $12 \mathrm{~h}$ intervals, starting when the largest follicle was $>5.7 \mathrm{~mm}$ in diameter. Data were obtained when the largest follicle was $\geqslant 8.5 \mathrm{~mm}$ in diameter (expected beginning of deviation).

IGF-I: insulin-like growth factor I; IGFBP-2: insulin-like growth factor binding protein 2.

aFollicle: follicle effect; treatment: treatment effect; ns: not significant. There were no follicle by treatment interactions.

LH concentrations were associated with lower oestradiol concentrations in the follicular fluid at the expected start of deviation (main effect of treatment). Ginther et al. (2001) did not find lower oestradiol concentrations in the follicular fluid of the largest follicle near the expected start of deviation (largest follicle $8.7 \mathrm{~mm}$ in diameter) in association with reduced $\mathrm{LH}$, but did find such an effect after the start of deviation (largest follicle $10.8 \mathrm{~mm}$ in diameter). The results for both of the present experiments support the hypothesis that increased synthesis and secretion of oestradiol into the circulation starting at deviation is a function of the transient $\mathrm{LH}$ increase that encompasses deviation. The results further support the conclusion (Ginther et al., 2000a) that the oestradiol that contributes to the continued decrease in FSH concentration after the start of deviation is from the largest follicle. Although the higher FSH concentrations are attributed to lower oestradiol, which, in turn, is attributed to lower LH, a direct effect of the exogenous progesterone on FSH cannot be ruled out. In addition to a systemic role in the continued decrease in FSH concentration, the increasing oestradiol concentration may be important locally for increasing the responsiveness of the largest follicle to the low concentrations of FSH (Ginther, 2000).

The prevention of the transient increase in $\mathrm{LH}$ concentration, the decrease in $\mathrm{FSH}$ concentration after deviation and the oestradiol increase at the start of expected deviation without altering the mean time and follicle characteristics of expected deviation indicate that these hormonal changes are not required for establishing the diameter aspects of deviation. The continued FSH decrease after the start of deviation may be important for other functions, such as preventing the emergence of a new follicular wave. However, the three waves with the longest interval from treatment to observed deviation all occurred in the treated groups and the difference in time to observed deviation tended to be longer in the treated group. Despite the absence of a difference between groups for expected deviation, the apparent delay of observed deviation in some waves indicates that the hormonal changes may provide assurance for the timely development of observed deviation, although further study is needed.

In vitro studies have shown that IGF-I stimulates mitosis of bovine granulosa cells and theca cells and increases oestradiol and androgen synthesis (Stewart et al., 1995; Spicer and Stewart, 1996; Khamsi and Armstrong, 1997). The present findings are consistent with a role for IGF-I in facilitating increased growth and oestradiol production by the developing dominant follicle after deviation has started (Ginther et al., 2001) but do not implicate IGF-I in initiating deviation. Unlike oestradiol, no difference was found in free IGF-I concentration between the two largest follicles at the expected start of deviation. No differences between follicles were detected for IGFBP-2, but Mihm et al. (2000) reported that IGFBP-4 concentrations were higher in the follicular fluid of the second and third largest follicles than in the largest follicle when it reached $7.6 \mathrm{~mm}$ in diameter. The IGFBPs may exert a role in bioavailability of IGF-I by binding to IGF-I and negating its potential trophic activity (Adashi, 1994).

In Expt 2, experimental reduction of $\mathrm{LH}$ was associated with a decrease in free IGF-I concentration in the follicular fluid averaged over the two largest follicles at the expected start of deviation. This result supported the hypothesis that the transient $\mathrm{LH}$ increase that encompasses deviation is required for normal IGF-I production. The LH reduction was associated with an increase in IGFBP-2 as well as a decrease in free IGF-I in both follicles. In this regard, the decrease in free IGF-I and increase in IGFBP-2 in LHreduced heifers may be related to the reduced growth of the dominant follicle after deviation. IGFBP-2 is secreted by the 
granulosa cells in bovine ovaries (Armstrong et al., 1998); however, an effect of LH on IGFBP-2 has not been reported previously. It is not known whether the effect of $\mathrm{LH}$ on free IGF-I and IGFBP-2 was exerted directly on the IGF system or was secondary to other effects, such as the stimulation of oestradiol. However, LH has been reported to increase the secretion of IGF-I from pig granulosa cells in vitro directly (Hsu and Hammond, 1987) and, conversely, IGF-I increases the number of $\mathrm{LH}$ receptors of bovine theca cells (Stewart et al., 1995). In addition to a possible role in the trophic effects of LH on the dominant follicle, IGF-I, as well as oestradiol, may increase the sensitivity of the granulosa cells to FSH (Monniaux et al., 1997). The ability of the more developed largest follicle to use the low concentrations of FSH after deviation has been demonstrated by Ginther et al. (2000b).

Progesterone concentrations were not different between the two largest follicles, but the variation was considerable. Beg et al. (2001) and Ginther et al. (2001) have found higher concentrations in the largest follicle. Unlike for oestradiol, the present experiments did not indicate that changes in concentration of circulatory or intrafollicular immunoreactive inhibin were related temporally to the time of deviation. Previous studies on the relationship between immunoreactive inhibin concentrations in follicular fluid and deviation also produced negative results (Beg et al., 2001; Ginther et al., 2001). Conclusions on the role of inhibin in deviation in cattle are not likely to be clarified until assays are used that can distinguish between immunoreactive and bioactive forms. Intrafollicular progesterone and immunoreactive inhibin concentrations were not affected by reduced $\mathrm{LH}$ concentrations at the start of deviation. However, a decrease in progesterone in assocition with reduced LH occurred after deviation in a study by Ginther et al. (2001). The reduction in concentrations of oestrone and androstenedione in the progesterone-treated group in the present study indicates that LH stimulated the oestradiol increase through the steroidogenic pathway. Although the oestrogenic effects of $\mathrm{LH}$ are well known (Fortune and Quirk, 1988), the present studies are the first to indicate that the relationship between $\mathrm{LH}$ and oestrogen is a component of the deviation mechanism.

In conclusion, the present results are consistent with previous reports that the largest follicle secretes increased oestradiol near the start of deviation in cattle, which contributes to the continued decrease in FSH concentrations. More importantly, the results of the present study indicate, for the first time, that near the start of deviation the secretion of increased oestradiol into the circulation and increased intrafollicular concentrations of oestradiol, IGF-I and androstenedione and the decreased concentrations of IGFBP-2 are functions of the LH increase that encompasses deviation. These results indicate that the $\mathrm{LH}$ increase encompassing deviation, the oestradiol increase that occurs systemically and in the follicles at the start of deviation, and the continuing decrease in FSH concentrations after the start of deviation are not required for establishing the time of expected deviation. However, there was some indication that one or all of these hormonal changes provide assurance for the timely development of observed deviation, at least in some waves.

This research was supported by the University of WisconsinMadison, Madison, WI, and The Eutherian Foundation, Cross Plains, WI.

\section{References}

Adams GP, Matteri RL and Ginther OJ (1992a) Effect of progesterone on ovarian follicles, emergence of follicular waves and circulating folliclestimulating hormone in heifers Journal of Reproduction and Fertility 95 627-640

Adams GP, Matteri RL, Kastelic JP, Ko JCH and Ginther OJ (1992b) Association between surges of follicle-stimulating hormone and the emergence of follicular waves in heifers Journal of Reproduction and Fertility 94 177-188

Adashi EY (1994) The intraovarian IGF hypothesis: a 1994 perspective Journal of Reproduction and Fertility Abstract Series 14 S3

Armstrong DG, Baxter G, Gutierrez CG, Hogg CO, Glazyrin AL, Campbell BK, Bramley TA and Webb R (1998) Insulin-like growth factor binding protein-2 and -4 messenger ribonucleic acid expression in bovine ovarian follicles: effect of gonadotropins and developmental status Endocrinology $1392146-2154$

Beg MA, Bergfelt DR, Kot K, Wiltbank MC and Ginther OJ (2001) Follicular-fluid factors and granulosa-cell gene expression associated with follicle deviation in cattle Biology of Reproduction 64 432-441

Bergfelt DR, Kulick LJ, Kot K and Ginther OJ (2000) Response of follicles to experimental suppression of FSH during follicular deviation in cattle Theriogenology 54 1191-1206

Evans ACO, Komar CM, Wandji S-A and Fortune JE (1997) Changes in androgen secretion and luteinizing hormone pulse amplitude are associated with the recruitment and growth of ovarian follicles during the luteal phase of the bovine estrous cycle Biology of Reproduction $\mathbf{5 7}$ 394-401

Fortune JE and Quirk SM (1988) Regulation of steroidogenesis in bovine preovulatory follicles Journal of Animal Science 66 (Supplement 2) 1-8

Gastal EL, Bergfelt DR, Nogueira GP, Gastal MO and Ginther OJ (1999) Role of luteinizing hormone in follicle deviation based on manipulating progesterone concentrations in mares Biology of Reproduction $\mathbf{6 1}$ 1492-1498

Ginther OJ (1998) Ultrasonic Imaging and Animal Reproduction: Book 3, Cattle pp 46 and 100. Equiservices Publishing, Cross Plains

Ginther OJ (2000) Selection of the dominant follicle in cattle and horses Animal Reproduction Science 60-61 61-79

Ginther OJ, Kot K, Kulick LJ and Wiltbank MC (1997) Sampling follicular fluid without altering follicular status in cattle: oestradiol concentrations early in a follicular wave Journal of Reproduction and Fertility 109 181-186

Ginther OJ, Bergfelt DR, Kulick LJ and Kot K (2000a) Selection of the dominant follicle in cattle: role of estradiol Biology of Reproduction $\mathbf{6 3}$ 383-389

Ginther OJ, Bergfelt DR, Kulick LJ and Kot K (2000b) Selection of the dominant follicle in cattle: role of two-way functional coupling between follicle-stimulating hormone and the follicles Biology of Reproduction 62 920-927

Ginther OJ, Bergfelt DR, Beg MA and Kot K (2001) Follicle selection in cattle: role of luteinizing hormone Biology of Reproduction 64 197-205

Hsu CJ and Hammond JM (1987) Gonadotropins and estradiol stimulate immunoreactive insulin-like growth factor-I production by porcine granulosa cells in vitro. Endocrinology 120 198-207

Khamsi F and Armstrong DT (1997) Interaction between follicle-stimulating hormone and growth factors in regulation of deoxyribonucleic acid synthesis in bovine granulosa cells Biology of Reproduction 57 684-688

Mihm M, Austin EJ, Good TEM, Ireland JLH, Knight PG, Roche JF and Ireland J (2000) Identification of potential intrafollicular factors 
involved in selection of dominant follicles in heifers Biology of Reproduction 63 811-819

Monniaux D, Huet C, Besnard N, Clément F, Bosc M, Pisselet C, Monget P and Mariana JC (1997) Follicular growth and ovarian dynamics in mammals Journal of Reproduction and Fertility Supplement 51 3-23

Roser JF, McCue PM and Hoye E (1994) Inhibin activity in the mare and stallion Domestic Animal Endocrinology 11 887-900

Spicer LJ and Stewart RE (1996) Interactions among basic fibroblast growth factor, epidermal growth factor, insulin and insulin-like growth factor-I (IGF-I) on cell numbers and steroidogenesis of bovine thecal cells: role of IGF-I receptors Biology of Reproduction 54 255-263

Stewart RE, Spicer LJ, Hamilton TD and Keefer BE (1995) Effects of insulinlike growth factor-I and insulin on proliferation and on basal and luteinizing hormone-induced steroidogenesis of bovine thecal cells: involvement of glucose and receptors for insulin-like growth factor I and luteinizing hormone Journal of Animal Science 73 3719-3731

Turzillo AM and Fortune JE (1990) Suppression of the secondary FSH surge with bovine follicular fluid is associated with delayed ovarian follicula development in heifers Journal of Reproduction and Fertility $\mathbf{8 9}$ 643-653

Received 2 January 2001.

First decision 2 March 2001

Accepted 21 March 2001 